\title{
WIND EROSION BY SNOW
}

\author{
By R. V. Dietrich \\ (Department of Geology, Central Michigan University, Mount Pleasant, Michigan 48859, U.S.A.)
}

Abstract. Calcite (Mohs hardness 3), fluorite (hardness 4) and periclase (hardness $5 \frac{1}{2}$ ) have been eroded by snow blown at moderate wind velocities, at temperatures between -10 and $-25^{\circ} \mathrm{C}$. Future interpretations involving ventifacts and apparently wind-blasted rock exposures must take this information into account.

RÉsumé. Érosion eolienne par la neige. De la calcite (échelle de dureté 3), de la fluorite (dureté 4) et de la périclase (dureté $5 \frac{1}{2}$ ) ont subi une érosion par de la neige souffée à des vitesses de vent modérées, à des températures allant de -10 à $-25^{\circ} \mathrm{C}$. Des interprétations futures comprenant les vents réels et les expositions apparentes des rochers au souffle du vent devront tenir compte de ces résultats.

Zusammenfassung. Wind-Erosion durch Schnee. Calcite (Härte 3), Fluorite (Härte 4) und Periclase (Härte 5 ,5) wurden durch Schnee erodiert, der bei Temperaturen zwischen - io und $-25^{\circ} \mathrm{C}$ unter mässigen Geschwindigkeiten angeweht wurde. Künftige Untersuchungen über Windformen und offensichtlich durch Wind freigelegte Felsformationen müssen diese Erkenntnis berücksichtigen.

Along with his summary of published data about the hardness of ice and descriptions of wind-eroded features spatially associated with glaciation, Teichert (1939, p. I47) concluded "There is thus no doubt that snow at low temperatures possesses the physical properties required for corrasion effects even on hard rocks". His "low temperature" requirement was based on the fact that the hardness of ice increases with decreasing temperature-for example, to 4 (Mohs scale) at $-44^{\circ} \mathrm{C}$ and $\approx 6$ at $-78.5^{\circ} \mathrm{C}$ (for this latter figure see Blackwelder (1939, p. 6r)).

Calculations made during our study of ventifacts (Whitney and Dietrich, 1973, p. 2577) indicate that the relative hardnesses of the missile and the target are not, as such, responsible for whether there is or is not erosion. Rather the kinetic energy of the missile and the bond strength of the target material determine the result. This, of course, means that hitting a relatively hard material target with a relatively soft material projectile could result in breakage of the former as well as of the latter. The main controls would be the effective mass of the missile ("effective" rather than actual because of differences in shapes and sizes of collision surfaces), the velocity of the missile, angular relationships at impact, and certain physical properties of the materials involved.

Recently, I have completed experiments that show the reported calculations do obtain. Among the experiments was one in which snow was blown against cleavage blocks of calcite (Mohs hardness 3 ), fluorite (hardness 4) and periclase (hardness $5 \frac{1}{2}$ ). The snow had irregularly shaped silt-sized particles of naturally agglomerated ice crystals. The temperature ranged between - 10 and $-25^{\circ} \mathrm{C}$ which indicates that the ice had a hardness ranging between approximately 2 and $3 \frac{1}{2}$. The wind velocities were from I4 to 23 m.p.h. ( $\approx 6.2$ to $10.3 \mathrm{~m} \mathrm{~s}^{-1}$ ).

Abrasion of the minerals used as targets was readily apparent within a few minutes. Breakage of pieces from corners and edges of the targets along with pitting of the fluorite were the obvious macroscopic wind-blast features. These and microscopic features-all similar to those known to have been formed by wind-blown dust and fine silt-will be described in a forthcoming paper.

Although the experimental results support Teichert's conclusion that rocks can be abraded by windblown snow, it does not support his implication that such erosion occurs only at temperatures below which the hardness of snow (ice) is equal to or greater than the hardnesses of the abraded constituents of the target rocks. Instead, it shows that wind-blown, relatively soft snow may be an effective tool for rock abrasion. In addition, the experiment indicates that such snow projectiles may be effective tools even when impelled by only moderate winds - that is, the missile fragments do not need to have velocities generally designated as of gale or hurricane strength.

Briefly stated, the experiment shows that particles of snow blown at moderate wind speeds may abrade rocks. This possibility of erosion by wind-blown snow should be kept in mind by geomorphologists, glaciologists, paleoclimatologists and others who study and interpret occurrences of ventifacts and wind-eroded bedrock.

MS. received 29 January 1976 and in revised form 29 March 1976 


\section{REFERENCES}

Blackwelder, E. 1939. The hardness of ice. American Journal of Science, Vol. 238, No. I, p. 61-62.

Teichert, C. 1939. Corrasion by wind-blown snow in polar regions. American fournal of Science, Vol. 237, No. 2, p. $146-48$.

Whitney, M. I., and Dietrich, R. V. 1973. Ventifact sculpture by windblown dust. Geological Society of America. Bulletin, Vol. 84 , No. 8, p. $2561-82$. 